\title{
Existing Land Use, Cropping Pattern and Resource Use Efficiency in Bardhaman District of West Bengal
}

\author{
Arnab Roy $^{1^{*}}$, G. Chaitra ${ }^{2}$ and Manjuprakash ${ }^{2}$ \\ ${ }^{1}$ Department of Agricultural Economics, ${ }^{2}$ Department of Agricultural Extension, University of \\ Agricultural Sciences, GKVK, Bengaluru-560065, India \\ *Corresponding author
}

A B S T R A C T

\section{Keywords}

DEA software,

Allocative

efficiency,

Technical

Article Info

Accepted:

15 January 2019

Available Online:

10 February 2019
The present article analyses the nature of crop diversification in terms of the changes in cropping pattern with respect to acreage and production distribution. From both the aspects of area and production it is observed that over the time span of three decades the cropping pattern in West Bengal is increasingly dominated by boro paddy, oilseeds (including, rapeseed and mustard) and potato. Pulses, as a whole, have lost both in terms of acreage and production in West Bengal. The Technical efficiency (TE), allocative efficiency (AE) and economic efficiency (EE) are calculated using the DEA software under the assumption of Variable returns to scale and (Table 9.1). The EE scores for crops grown under rainfed condition range from 0.03 in the case of cowpea to 0.85 for Sugarcane; The TE scores for rainfed condition ranged from 0.46 in the case of cowpea to 0.98 in the case of Sugarcane; The EE scores for crops grown under irrigated condition range from 0.10 in the case of red gram and green gram to 0.57 for Paddy; The TE scores for irrigated condition ranged from 0.41 in the case of greengram to 0.97 in the case of paddy.

\section{Introduction}

Agriculture plays a dominant role in economic development through supplying food for the nation, generating opportunities of employment, and sharing of national GDP as well as providing raw materials for agrobased industries (Johnstone and Mellor, 1961). In India, $60 \%$ of people are dependent on agriculture (Paul, 2015). During 1985-86 and 1992-93, the agricultural contribution to the SDP was increasing at about 4.7 per cent per annum, while the overall growth was 5.1 per cent per annum. A number of facilities for irrigation have been opened up and the consumption of chemical fertilisers has gone up from 558 thousand tonnes to 1109 thousand tonnes in between 1985-90 and 1997-02. This point is to an increase in the application of fertilisers to the extent of over 36 per cent. Aided by these improvements in the use of hyv rice almost is doubled between 1985-86 and 1992-93(Sarkar, 2018).

West Bengal to this date remains primarily an agricultural state with ten of its districts deriving 30 per cent or more of their net district domestic product from agriculture. 
Although the share of agriculture in the net state domestic product is continuously falling in West Bengal, the state continues to depend heavily on agriculture. Agriculture occupies an important place in the economy of West Bengal. It not only provides food to the large and fast growing people but also raw materials to numerous agro-based industries. About 70 per cent of the working population is directly or indirectly engaged in agriculture. In the last three decades agriculture has shifted from subsistence to commercial agriculture. The state of West Bengal is one of the fertile regions in the country.

\section{Nature and sources of data}

Both the secondary data and primary [CCS data] were used in the study. Secondary data sources for few indicators like for subsidy rate on fertilizers and electricity the data were procured from the Department of Agriculture, DES, GoI and West Bengal State. Statistical Abstract of West Bengal (Various issues) has been used to collect data on various cropping and irrigation parameters of state's agriculture (Table 1).

\section{Analytical tools and techniques employed}

\begin{tabular}{|l|l|}
\hline$*$ Items & Tool/Techniques \\
\hline $\begin{array}{l}\text { Changes in } \\
\text { cropping } \\
\text { pattern Land } \\
\text { use pattern }\end{array}$ & Diversification index \\
\hline $\begin{array}{l}\text { Resource use } \\
\text { efficiency }\end{array}$ & $\begin{array}{l}\text { Data Envelopment Analysis } \\
\text { (DEA) approach }\end{array}$ \\
\hline $\begin{array}{l}\text { Scope of } \\
\text { revising crop } \\
\text { plans }\end{array}$ & $\begin{array}{l}\text { Cost-return analysis using } \\
\text { Market Prices, Economic } \\
\text { Prices and Natural Resource } \\
\text { Valuation Prices }\end{array}$ \\
\hline
\end{tabular}

\section{Estimation of cost and returns}

The costs were classified into variable and fixed costs. Variable cost includes cost of inputs, labour cost, interest on working capital and miscellaneous costs. Fixed costs were defined to include depreciation on farm implements, land revenue and taxes. While the returns included value of both main product and by-product.

\section{Technical, allocative and cost efficiencies}

Technical efficiency (TE) refers to the ability of a farm to produce the maximum feasible output from a given bundle of inputs, or the minimum feasible amounts of inputs to produce a given level of output. Allocative efficiency (AE) refers to the ability of a technically efficient farm to use inputs in proportions that minimize production costs given input prices.

Allocative efficiency is calculated as the ratio of the minimum costs required by the farm to produce a given level of outputs and the actual costs of the farm adjusted for TE. Economic Efficiency (EE) is the product of TE and AE. Thus, a farm is economically efficient if it is both technically and allocatively efficient. The popular method of estimating the maximum possible output has been the Data Envelopment Analysis (DEA) advocated by Charneset.al.(1978).

\section{Data envelopment analysis}

The DEA method is a frontier method that does not require specification of a functional form or a distributional form, and can accommodate scale issues.

DEA was applied by using both classic models CRS (constant returns to scale) with input orientation, in which one seeks input minimization to obtain a particular product level. Under assumption of constant returns to scale, the linear programming models for measuring the efficiency of farms are (Coelli et al., 1998). 


\section{Estimation of technical efficiency}

$\operatorname{Min} \theta \lambda \theta$

Subject to $-\mathrm{yi}+\mathrm{Y} \lambda \geq 0$

$\theta \mathrm{Xi}-\mathrm{X} \lambda \geq 0$

$\lambda \geq 0$

Where,

yi is a vector $(m \times 1)$ of output of the $\mathrm{i}$ th Producing Farms (TPF)

$x i \quad$ is a vector $(k \times 1)$ of inputs of the $\mathrm{i} t h$ TPF

$Y \quad$ is an output matrix $(n \times m)$ for $\mathrm{n}$ TPFs

$X \quad$ is an input matrix $(n \times k)$ for $n$ TPFs

$\theta$ is the efficiency score, a scalar whose value will be the efficiency measure for theithTPF. If $\theta=1, \operatorname{TPF}$ (Total productivity factor) will be efficient; otherwise, it will be inefficient.

$\lambda$ is a vector $(n x l)$ whose values are calculated to obtain the optimum solution. For an inefficient TPF, the $\lambda$ values will be the weights used in the linear combination of other, efficient, TPFs which influence the projection of the inefficient TPF on the calculated frontier.

\section{Estimation of allocative efficiency and cost efficiency (economic efficiency)}

If one has price information and is willing to consider a behavioural objective, such as cost minimization or revenue maximization, then one can measure both technical and allocative efficiencies. One would run the following cost minimization DEA for estimation of cost efficiency (or economic efficiency) as follows:

$\operatorname{Min}_{\lambda, \mathrm{Xi}^{*}} \mathrm{Wi} \mathrm{Xi*}$

Subject to $-\mathrm{yi}+\mathrm{Y} \lambda \geq 0$,

$\mathrm{Xi}^{*}-\mathrm{X} \lambda \geq 0$,

$\mathrm{N}_{1} \lambda \geq 1$

$\lambda \geq 0$,
Where,

Wi is a vector of input prices for the $\mathrm{i}^{\text {th }}$ Total Productivity Factor (TPF),

$\mathrm{Xi}$ is the cost minimizing vector of input quantities for the $\mathrm{i}^{\text {th }}$ TPF (which is calculated by the LP),

Given the input prices $\mathrm{Wi}$ and the output levels Yi. The total cost efficiency (CE) or economic efficiency of the $i^{\text {th }}$ TPF would be calculated as

$\mathrm{CE}=\mathrm{WiXi} * / \mathrm{WiXi}$.

i.e., the ratio of minimum cost to observed cost. One can then use equation 6 to calculate the allocative efficiency residually as

$\mathrm{AE}=\mathrm{CE} / \mathrm{TE} \ldots \ldots \ldots \ldots \ldots \ldots \ldots \ldots . . .(7)$

\section{Results and Discussion}

\section{Diversification index for the West Bengal}

In the present study, among the various indices of studying the extent of crop diversification at a given point of time like Herfindahl Index (HI); Transformed Herfindahl Index (THI); Ogive Index (OI); Entropy Index (EI); Modified Entropy Index (MEI); Composite Entropy Index (CEI); Gini's Coefficient (Gi); and Simpson Index (SI) of Diversification has been employed to measure degree of crop diversification and is explained as follows:

$\mathrm{SI}=1-\Sigma(\text { pi } / \Sigma \text { pi })^{2}$

Where, pi is the area proportion of the ith crop in total cropped area and $i=1,2,3, \ldots . n$. is the number of crops. This index was first used to measure the regional concentration of industries (Theil, 1967).

The value of $\mathrm{HI}$ is bounded by 0 (perfect diversification 4) and 1 (complete specialization). 
Table.1 Land use pattern in West Bengal state during the period 1980-81 to 2011-12

\begin{tabular}{|c|c|c|c|c|c|c|c|c|c|c|}
\hline & 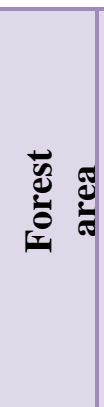 & 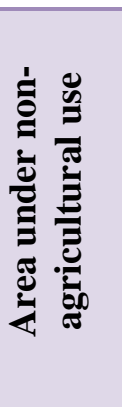 & 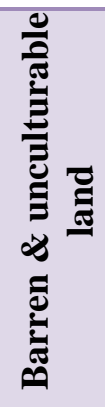 & 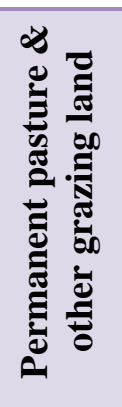 & 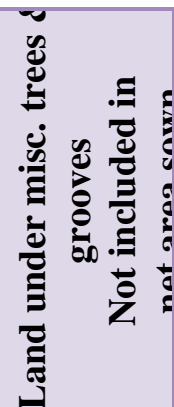 & 施 & 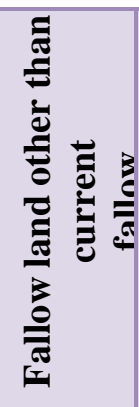 & 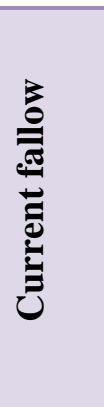 & 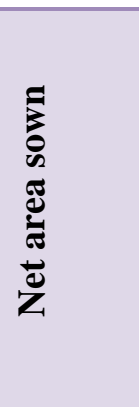 & 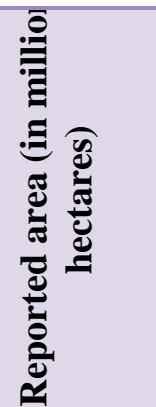 \\
\hline India & 22.66 & 7.70 & 6.29 & 3.56 & 1.10 & 4.46 & 3.33 & 4.83 & 46.07 & 306.26 \\
\hline $\begin{array}{l}\text { West } \\
\text { Bengal }\end{array}$ & 13.48 & 18.52 & 0.31 & 0.06 & 0.67 & 0.40 & 0.25 & 3.84 & 62.89 & 9.69 \\
\hline
\end{tabular}

Table.2 Cropping pattern from sample data under Rainfed situation TE-2014-15

\begin{tabular}{|r|l|r|r|r|}
\hline SN & \multicolumn{1}{|c|}{ Particulars } & $\begin{array}{c}\text { n } \\
\text { (No. of observations) }\end{array}$ & $\begin{array}{c}\text { TE 2014-15 } \\
\text { (ha) }\end{array}$ & $\begin{array}{c}\text { \% of } \\
\text { Sample GCA }\end{array}$ \\
\hline $\mathbf{1}$ & Bajra & 18 & 62.60 & 1.53 \\
\hline $\mathbf{2}$ & Mustard & 183 & 742.90 & 18.17 \\
\hline $\mathbf{3}$ & Maize & 18 & 62.60 & 1.53 \\
\hline $\mathbf{4}$ & Paddy & 228 & 939.21 & 22.97 \\
\hline $\mathbf{5}$ & Potato & 183 & 742.90 & 18.17 \\
\hline $\mathbf{6}$ & Wheat & 48 & 193.89 & 4.74 \\
\hline $\mathbf{7}$ & Cowpea & 10 & 36.09 & 0.88 \\
\hline $\mathbf{8}$ & Gram & 18 & 55.38 & 1.35 \\
\hline $\mathbf{9}$ & Green gram & 52 & 183.87 & 4.50 \\
\hline $\mathbf{1 1}$ & Sugarcane & 61 & 200.03 & 4.89 \\
\hline $\mathbf{1 2}$ & Jute & 95 & 373.44 & 9.13 \\
\hline $\mathbf{1 3}$ & Safflower & 12 & 49.42 & 1.21 \\
\hline $\mathbf{1 4}$ & Cotton & 7 & 23.25 & 0.57 \\
\hline & Gross cropped area & $\mathbf{1 0 4 5}$ & $\mathbf{4 0 8 9 . 2 7}$ & $\mathbf{1 0 0 . 0 0}$ \\
\hline
\end{tabular}

Source: Government of West Bengal, Bureau of Applied Economics and Statistics 
Table.3 Growth rate of output of crops/crop groups in West Bengal during 1990-91 to 2014-15

\begin{tabular}{|l|c|}
\hline \multicolumn{1}{|c|}{ Crops } & $\begin{array}{c}\text { Growth Rate of } \\
\text { Output }\end{array}$ \\
\hline 1. Rice & 92.16 \\
2. Aus & 1.84 \\
3. Aman & 51.17 \\
4. Boro & 399.38 \\
\hline Potato & 402.12 \\
\hline Sugarcane & 1643.46 \\
\hline Jute & 84.93 \\
\hline Total food Grains & 91.52 \\
\hline Rapeseed \& Mustard & 326.65 \\
\hline Total pulses & -23.46 \\
\hline
\end{tabular}

Source: Government of West Bengal, Bureau of Applied Economics and Statistics

Table.4 Crop diversification index for West Bengal state

\begin{tabular}{|l|c|c|c|}
\hline Particulars & TE 1994-95 & TE 2004-05 & TE 2014-15 \\
\hline $\begin{array}{l}\text { Simpson Diversity Index (SDI) } \\
\text { during triennium ending }\end{array}$ & 0.7698 & 0.7883 & 0.8002 \\
\hline
\end{tabular}

Table.5a Technical, allocative and economic efficiency of crops by considering variable returns to scale in West Bengal TE 2014-15

\begin{tabular}{|l|l|c|c|c|}
\hline SN & Crops & \multicolumn{3}{|c|}{ Rainfed } \\
\cline { 3 - 5 } & & TE & AE & EE \\
\hline & Paddy & 0.97 & 0.72 & 0.70 \\
\hline & Maize & 0.74 & 0.42 & 0.31 \\
\hline & Wheat & 0.90 & 0.90 & 0.81 \\
\hline & Cowpea & 0.46 & 0.06 & 0.03 \\
\hline & Gram & 0.61 & 0.17 & 0.10 \\
\hline & Greengram & 0.98 & 0.68 & 0.67 \\
\hline & Redgram & 0.51 & 0.31 & 0.16 \\
\hline & Soyabean & 0.82 & 0.58 & 0.48 \\
\hline & Groundnut & 0.55 & 0.37 & 0.20 \\
\hline & Sugarcane & 0.98 & 0.87 & 0.85 \\
\hline & Mustard & 0.85 & 0.68 & 0.58 \\
\hline $\mathbf{1 3}$ & Potato & 0.71 & 0.7 & 0.50 \\
\hline
\end{tabular}


Table.5b Technical, allocative and economic efficiency of crops by considering variable returns to scale in West Bengal TE 2014-15

\begin{tabular}{|l|l|c|c|c|}
\hline \multirow{2}{*}{ SN } & Crops & \multicolumn{3}{|c|}{ Irrigated } \\
\cline { 3 - 5 } & & TE & AE & EE \\
\hline & Paddy & 0.97 & 0.59 & 0.57 \\
\hline & Maize & 0.60 & 0.60 & 0.36 \\
\hline & Wheat & 0.82 & 0.58 & 0.48 \\
\hline & Cowpea & 0.60 & 0.39 & 0.23 \\
\hline & Gram & 0.50 & 0.41 & 0.21 \\
\hline & Redgram & 0.63 & 0.16 & 0.10 \\
\hline & Potato & 0.79 & 0.77 & 0.61 \\
\hline & Sugarcane & 0.91 & 0.50 & 0.46 \\
\hline & Groundnut & 0.50 & 0.40 & 0.20 \\
\hline & Mustard \& Rapeseed & 0.64 & 0.58 & 0.37 \\
\hline & Soyabean & 0.53 & 0.38 & 0.20 \\
\hline & Greengram & 0.41 & 0.25 & 0.10 \\
\hline
\end{tabular}

Fig.1 Crop wise farm technical, efficiency, allocative and economic efficiency

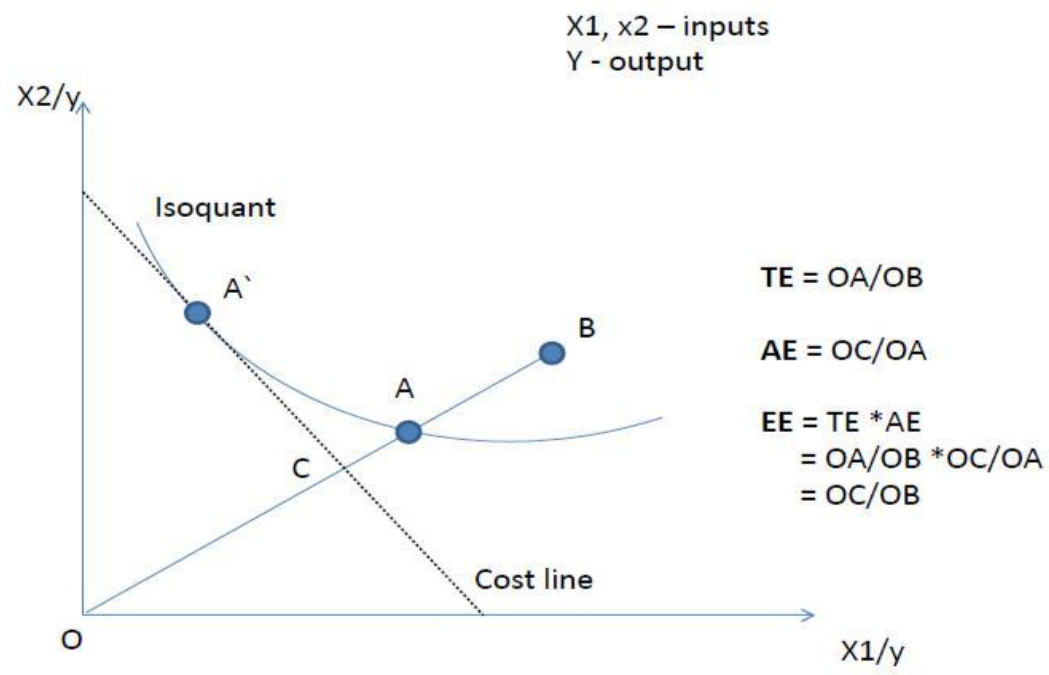

\section{Cropping pattern on sample farms}

It could be observed from the Table 2 that rice was the major crop on the sample farms accounting for about 23 per cent followed by potato, sugarcane and mustard which together accounted for $2 / 3^{\text {rd }}$ of the GCA and jute was the leading crop among oilseeds under rainfed situation.

As expected under canal irrigated situation paddy being the more water intensive crop accounted for about 60 per cent of the GCA, rice and potato are the other two distantly 
competing crops for area with a share of about ten and seven per cent of the GCA on the sample farms.

Table 3 displays a contrast among the growth rates of different crops/crop groups during 1990-91 to 2014-15. From the table it can be observed that there has been a substantial growth in output over time in case of individual crops like boro rice, rapeseed and mustard, sugarcane and potato.

\section{Diversification index for the West Bengal}

Thus it could be inferred from the table 4 that the West Bengal state had a highly diversified cropping pattern as the value of SDI approached unity during the study period.

\section{Crop wise farm technical, efficiency,} allocative and economic efficiency

In simple terms, Technical Efficiency (TE) reflects the ability of the firm to obtain a given output with minimal input. The Allocative Efficiency (AE) reflects the ability of a firm to use the inputs in optimal proportions. The Economic Efficiency (EE) is the product of the two efficiencies. Figure 1 explains the concepts.

The TE, AE and EE are calculated using the DEA software under the assumption of Variable returns to scale and (Table 4). The EE scores for crops grown under rainfed condition range from 0.03 in the case of cowpea to 0.85 for Sugarcane; The TE scores for rainfed condition ranged from 0.46 in the case of cowpea to 0.98 in the case of Sugarcane;

The EE scores for crops grown under irrigated condition range from 0.10 in the case of red gram and green gram to 0.57 for Paddy; The TE scores for irrigated condition ranged from 0.41 in the case of greengram to 0.97 in the case of paddy; Table 5).
The present chapter has analysed the nature of crop diversification in terms of the changes in cropping pattern with respect to acreage and production distribution. From both the aspects of area and production it can be observed that over the time span of three decades the cropping pattern in West Bengal is increasingly dominated by boro paddy, oilseeds (including, rapeseed and mustard) and potato.

Besides being remunerative, oilseed crop also require less irrigation which makes them ideal for cultivation in the areas with less rain or irrigation. Pulses, as a whole, have lost both in terms of acreage and production in West Bengal.

The indices of diversification mostly indicate an increasing degree of crop diversification over time.

The growth rates of area and production of principal food grain crops like aus, aman, boro and potatoes show declining trends during the second sub-period or the postglobalisation period In conclusion, we can say that the cropping pattern change in West Bengal has indeed been an emerging reality which is reflected through adoption of a diversified crop-mix by the farmers.

\section{References}

Paul, A. 2015.Banglar Krishi O Krishak Samasya O Sombhabana, Naya Udyog Publication, Kolkata.

Suresh, A. AND Reddy, K. T. R. 2006. Resource-use efficiency of paddy cultivation in Peechi command area of Thrissur district of Kerala: An economic analysis. Agric. Econ. Res. Rev., 19: 159-171.

Johnston, B. F. and Mellor, J. W. 1961. 'The Role of Agriculture in Economic Development', American Economic 
Review, Vol. 51, in Kurosaki T. 2002. 'Agriculture in India and Pakistan, 1900-95: A Further Note', Economic and Political Weekly, 37(30): 566-93.

Chand, Ramesh, S.S. Raju and L.M. Pandey. 2008. "Progress and Potential of Horticulture in India", Indian Journal of
Agricultural Economics.63(3)299-309. Majumdar, K. and P. Basu. 2005. Growth decomposition of food grains output in west Bengal: A district level study. Indian J. Agric. Econ., 60: 220-234. http://cgwb.gov.in/District_Profile/westbenga 1/BROCHURE.pdf

\section{How to cite this article:}

Arnab Roy, G. Chaitra and Manjuprakash. 2019. Existing Land Use, Cropping Pattern and Resource Use Efficiency in Bardhaman District of West Bengal. Int.J.Curr.Microbiol.App.Sci. 8(03): 1805-1812. doi: https://doi.org/10.20546/ijcmas.2019.803.212 